\title{
HERBAGE YIELD AND BOTANICAL COMPOSITION OF GRASS-LEGUME MIXTURE AT DIFFERENT TIME OF ESTABLISHMENT
}

\author{
A. Simić ${ }^{1}$, S. Vasiljević ${ }^{2}$, S. Vučković ${ }^{1}$, Z. Tomić ${ }^{3}$, Z. Bjelić ${ }^{3}$, V. Mandić ${ }^{3}$ \\ ${ }^{1}$ University of Belgrade, Faculty of Agriculture, Zemun, Republic of Serbia \\ ${ }^{2}$ Institute of Field and Vegetable Crops, Novi Sad, Republic of Serbia \\ ${ }^{3}$ Institute for Animal Husbandry, Belgrade-Zemun, Republic of Serbia \\ Corresponding author: alsimic@agrif.bg.ac.rs \\ Original scientific paper
}

Abstract: For comparative testing of the total productivity of mixtures (intercrops) of red clover (Trifolium pratense L.) and Italian ryegrass (Lolium multiflorum L.), a trial was carried out during the 2007-2009 growing seasons at experimental fields of the Institute for Animal Husbandry, Belgrade-Zemun. Intercrops included two red clover varieties (K-17 and Una) and tetraploid Italian ryegrass $(\mathrm{K}-29 \mathrm{t})$ in different proportional ratios $(100: 0 \%, 75: 25 \%, 50: 50 \%, 25: 75 \%$ and 0:100\%). Italian ryegrass sown alone was top-dressed with nitrogen rates of 100 and $200 \mathrm{~kg} \mathrm{ha}^{-1}$. Herbage yields and botanical composition were influenced by different sowing times in the first production year. Spring seeded red clover was more persistent and cumulatively yielded, autumn seeded Italian ryegrass produced more dry matter in the mixture than red clover. The trial demonstrates the potential of two red clover cultivars grown either alone or with a suitable Italian ryegrass to achieve and maintain a high output of herbage of good quality in the first production year, with different time of stand establishment. The practical agricultural implications of using ryegrass/clover are discussed.

Key words: autumn sowing, botanical composition, grass/legume mixture, herbage yield, spring sowing

\section{Introduction}

The supply of fresh matter forage as periodically as possible represents one of the main objectives of cattle breeders in order to obtain constant milk productions. It is known that mixtures of perennial grasses and legumes produce nutritionally balanced forage (Sima et al., 2010), while providing a part of the protein, carbohydrate and mineral requirements. The choice of mixtures of perennial grasses and legumes, unlike pure crops of perennial grasses and legumes for the establishment of temporary pastures, provides the pre-requisites of 
sustainable forage production (Fornara and Tilman, 2008; Helgadóttir et al., 2008).

Grass-legume mixtures are preferred over pure-grass forage stands throughout the world because they often increase the total yields of herbage and protein and offer balanced nutrition (Albayrak et al., 2011). Mixtures offer several potential advantages over pure grasses or pure legumes. These advantages include the control of erosion, prolonged stand longevity and, especially, weed control. Wacquant et al. (1989) suggested that $\mathrm{NO}^{3-}$ enrichment results from $\mathrm{N}$ excretion from active nodulated roots of the legume, accounting for the increase in both biomass and nitrogen content of the companion grass in grass-legume association. Introduction of high quantities of $\mathrm{N}$ fertilizer can also lead to accumulation of $\mathrm{NO}^{3-}$ in plants, but also in soil, which can have negative consequences (Nešić et al. 2008).

Red clover is probably best grown in association with grass as the mixture increases dry matter (DM) yields and reduces sward weed problems. High annual DM yield have been reported from such grass/clover mixtures without the use of nitrogen fertilizer. In temporary and permanent grasslands, red clover distinctly increases herbage quality and production at low fertilization requirements (Hejduk and Knot, 2010). Red clover is the most important clover crop on moist, less fertile and temperate acidic soils while alfalfa predominates in drier regions on deep soils with neutral reaction. Red clover is currently grown in Serbia especially in pure stands on arable land, in mixtures with grasses and at a limited extent also in permanent swards (Vasiljević et al., 2010). Although the forage of alfalfa contains more crude protein as compared with red clover, the advantage of red clover is the presence of enzyme polyphenol oxidase (PPO), which improves protein efficiency during digestion of ruminants (Sulivan and Hatfield, 2006) and suppresses proteolysis during forage ensiling (Pahlow, 2003).

Both red clover and Italian ryegrass produce a vast amount of bulk, particularly Italian ryegrass in its first full harvest year from an autumn sowing. Red clover is an ideal companion as the upright, open growth of Italian ryegrass permits the right amount of space and light for the red clover plants to establish, produce good leaf growth and develop a deep root structure. This in turn means the red clover can very efficiently fix atmospheric nitrogen via its root nodules and therefore minimise the requirement of adding artificial $\mathrm{N}$ to the crop. Any grass seed ley containing red clover also has a much higher protein content (compared to ryegrass alone) maximising voluntary intake of the available forage. The $\mathrm{N}$ content is the greatest individual nutrition factor effecting the growth and development of Italian ryegrass (Simić et al., 2009). A principal limiting factor in ryegrass crops can be water deficit and among mineral elements nitrogen impedes the growth and yield the most.

The objective of this paper is to evaluate differences in yield, persistence and other features important with respect to agricultural production among red clover varieties from Serbia grown in simple mixtures with high productive Italian ryegrass. The most persistent variety should be used preferably for lays and for the 
establishment of permanent grasslands or sod seeding. The use of more persistent variety would lead to reduced requirements of nitrogen fertilizers, increased forage yield and quality as well as to extended intervals between red clover seeding into sod. This would consequently lead to decreased inputs in cattle rearing and reduced costs of animal products. It is necessary to test persistence under local conditions together with grass companion.

\section{Materials and Methods}

The red clover varieties (cv. Una and K-17) were sown in October 2007 (autumn sowing) and March 2008 (spring sowing) with Italian ryegrass (cv. K-29t) using different proportional ratios IR:RC (100:0 \%, 75:25\%, 50:50\%, 25:75\% and $0: 100 \%)$. Sowing rates were $15 \mathrm{~kg} \mathrm{ha}^{-1}$ of red clover and $30 \mathrm{~kg} \mathrm{ha}^{-1}$ of Italian ryegrass. The trial was established by the method of RCB design of plots $(3 \times 4 \mathrm{~m})$ in 4 repetitions. The plots were harvested two times in the first production year. In the year of sowing, the spring stand was harvested twice without assessment of production. No nitrogen fertilizer was applied. Italian ryegrass sown alone received nil or 100 and $200 \mathrm{~kg} \mathrm{ha}^{-1} \mathrm{~N}$. In the assessment of dry forage production and botanical composition, a composite sample was taken at each harvest from all the treatments. Dry matter (DM) yield was assessed and botanical analyses were conducted on herbage samples from each treatment at each of two stands (autumn and spring sowing) in the first production year. LER (Land Equivalent Ratio) index was calculated for each intercrop, considering that intercropping aims at not only forage quality improvement, but also at higher herbage yield. LER is the sum of the fractions of the intercropped yields divided by the sole-crop yields.

The results of soil analysis revealed a $\mathrm{pH}$-value of 7.29-7.23, which indicates a neutral reaction (Table 1). The total nitrogen content of the soil indicated a good supply in all experimental plots, as well as $\mathrm{P}$ and $\mathrm{K}$.

Table 1. The average values of some agrochemical soil parameters $(0-40 \mathrm{~cm}$ depth)

\begin{tabular}{|c|c|c|c|c|c|c|}
\hline Depth (cm) & $\begin{array}{c}\mathrm{pH} \\
\left(\mathrm{H}_{2} \mathrm{O}\right)\end{array}$ & $\begin{array}{c}\mathrm{pH} \\
(\mathrm{KCl})\end{array}$ & $\begin{array}{c}\mathrm{CaCO}_{3} \\
\mathrm{~g} \mathrm{~kg}^{-1}\end{array}$ & $\begin{array}{c}\text { Total N } \\
\mathrm{mg} \mathrm{kg}^{-1}\end{array}$ & $\begin{array}{c}\mathrm{P} \\
\mathrm{mg} \mathrm{kg}^{-1}\end{array}$ & $\begin{array}{c}\mathrm{K} \\
\mathrm{mg} \mathrm{kg}^{-1}\end{array}$ \\
\hline $0-20$ & 7.29 & 7.08 & 3.3 & 1975 & 909 & 162 \\
\hline $0-40$ & 7.23 & 7.09 & 4.7 & 1938 & 918 & 165 \\
\hline
\end{tabular}

Comparing meteorological data in 2 years (Table 2), it could be concluded that both years had similar weather conditions during growing period of Italian ryegrass and red clover. Climatic and soil conditions of the experimental field reflect most of forage producing areas occurring in the northern part of Serbia (chernozem soil). 
Table 2. Meteorological parameters

\begin{tabular}{|l|c|c|c|c|c|c|}
\hline \multirow{2}{*}{ Month } & \multicolumn{3}{|c|}{2008} & \multicolumn{3}{|c|}{2009} \\
\cline { 2 - 7 } & Temperature & Precipitation & $\begin{array}{c}\text { Rain } \\
\text { factor }\end{array}$ & Temperature & Precipitation & $\begin{array}{c}\text { Rain } \\
\text { factor }\end{array}$ \\
\hline I & 2.4 & 39.9 & & -0.9 & 59.2 & \\
\hline II & 5.4 & 7.9 & & 2.5 & 39.3 & \\
\hline III & 8.3 & 62.3 & 7.5 & 7.3 & 48.3 & 6.6 \\
\hline IV & 13.3 & 39.0 & 2.9 & 15.1 & 5.9 & 0.4 \\
\hline V & 18.8 & 36.4 & 1.9 & 19.0 & 42.2 & 2.2 \\
\hline VI & 22.7 & 81.9 & 3.6 & 20.5 & 90.7 & 4.4 \\
\hline VII & 23.2 & 49.0 & 2.1 & 23.6 & 52.0 & 2.2 \\
\hline VIII & 23.5 & 22.9 & 1.0 & 23.6 & 65.5 & 2.8 \\
\hline IX & 16.4 & 57.2 & 3.5 & 20.0 & 10.9 & 0.5 \\
\hline X & 14.1 & 12.6 & 0.9 & 12.8 & 84.5 & 6.6 \\
\hline XI & 8.5 & 45.7 & & 9.1 & 48.6 & \\
\hline XII & 4.2 & 66.4 & & 4.0 & 95.9 & \\
\hline Averege/Total & 13.4 & 521.2 & & 13.1 & 643.0 & \\
\hline
\end{tabular}

\section{Results and Discussion}

Red clover gives the highest yields most frequently right in the first year after stand establishment (Hejduk and Knot, 2010). In our experiment, however, pure sown Italian ryegrass gave the highest yield in autumn stand, especially with $\mathrm{N}$ application, which was conditioned by weather (Table 3). In 2008, the weather was humid in March (rain factor 7.5) and the spring growth of plants occurred early. There were good conditions for nitrogen supplying, and this is why very high yields of ryegrass were achieved.

Table 3. Vegetative yield of Italian ryegrass (IR) and red clover (RC) as pure stands and mixtures in the first production year, with two different times of stand establishment $\left(\mathrm{t} \mathrm{ha}^{-1}\right)$

\begin{tabular}{|c|c|c|c|c|c|c|}
\hline \multirow{2}{*}{ Treatment } & \multicolumn{3}{|c|}{ Autumn sowing } & \multicolumn{3}{|c|}{ Spring sowing } \\
\hline & $1^{\text {st }}$ cut & $2^{\text {nd }} \mathrm{cut}$ & Total DM & $1^{\text {st }}$ cut & $2^{\text {nd }}$ cut & Total DM \\
\hline IR & $5.22^{\mathrm{b}^{*}}$ & $1.04^{\mathrm{a}}$ & 6.26 & $2.05^{\mathrm{b}}$ & $0.26^{\mathrm{b}}$ & 2.25 \\
\hline $\mathrm{IR}+100 \mathrm{~kg} \mathrm{ha}^{-1} \mathrm{~N}$ & $9.80^{\mathrm{a}}$ & $1.05^{\mathrm{a}}$ & 10.85 & $3.83^{\mathrm{ab}}$ & $0.23^{\mathrm{b}}$ & 4.06 \\
\hline $\mathrm{IR}+200 \mathrm{~kg} \mathrm{ha}^{-1} \mathrm{~N}$ & $8.32^{\mathrm{ab}}$ & $1.09^{\mathrm{a}}$ & 9.41 & $4.39^{\mathrm{a}}$ & $0.31^{\mathrm{b}}$ & 4.70 \\
\hline IR+RC Una $(75: 25 \%)$ & $5.91^{b}$ & $0.76^{\mathrm{a}}$ & 6.67 & $3.84^{\mathrm{ab}}$ & $1.02^{\mathrm{a}}$ & 4.86 \\
\hline IR+RC Una (50:50\%) & $7.53^{\mathrm{ab}}$ & $0.71^{\mathrm{a}}$ & 8.24 & $4.08^{\mathrm{ab}}$ & $1.55^{\mathrm{a}}$ & 5.63 \\
\hline IR+RC Una $(25: 75 \%)$ & $4.53^{b}$ & $0.92^{\mathrm{a}}$ & 5.45 & $4.61^{\mathrm{a}}$ & $1.28^{\mathrm{a}}$ & 5.89 \\
\hline RC Una & $1.36^{\mathrm{c}}$ & $1.24^{\mathrm{a}}$ & 2.60 & $4.15^{\mathrm{ab}}$ & $1.14^{\mathrm{a}}$ & 5.29 \\
\hline IR+RC K-17 (75:25\%) & $6.14^{b}$ & $0.86^{\mathrm{a}}$ & 7.00 & $3.27^{\mathrm{ab}}$ & $1.04^{\mathrm{a}}$ & 4.31 \\
\hline IR+RC K-17 (50:50\%) & $8.11^{\mathrm{ab}}$ & $1.03^{\mathrm{a}}$ & 9.14 & $4.10^{\mathrm{ab}}$ & $1.33^{\mathrm{a}}$ & 5.43 \\
\hline IR+RC K-17 (25:75\%) & $4.71^{b}$ & $0.79^{\mathrm{a}}$ & 5.50 & $2.93^{\mathrm{ab}}$ & $1.43^{\mathrm{a}}$ & 4.36 \\
\hline RC K-17 & $4.72^{b}$ & $1.24^{\mathrm{a}}$ & 5.96 & $4.31^{\mathrm{a}}$ & $1.52^{\mathrm{a}}$ & 5.83 \\
\hline
\end{tabular}

*Means in columns followed by the same letter are not significantly different by Fisher's protected $\mathrm{LSD}$ values $(\mathrm{P}=0.05)$ 
The highest yield was obtained using $100 \mathrm{~kg} \mathrm{ha}^{-1} \mathrm{~N}$, confirming that lower rates of nitrogen fertilizers affect primarily the increase of forage yield while higher rates increase the CP content (Simić et al., 2009). Autumn sowing stand was more productive than spring sowing stand and reached total herbage production levels of $10.85 \mathrm{t} \mathrm{DM} \mathrm{ha}^{-1}$ compared with $4.06 \mathrm{t} \mathrm{DM} \mathrm{ha}^{-1}$ for ryegrass sown in spring.

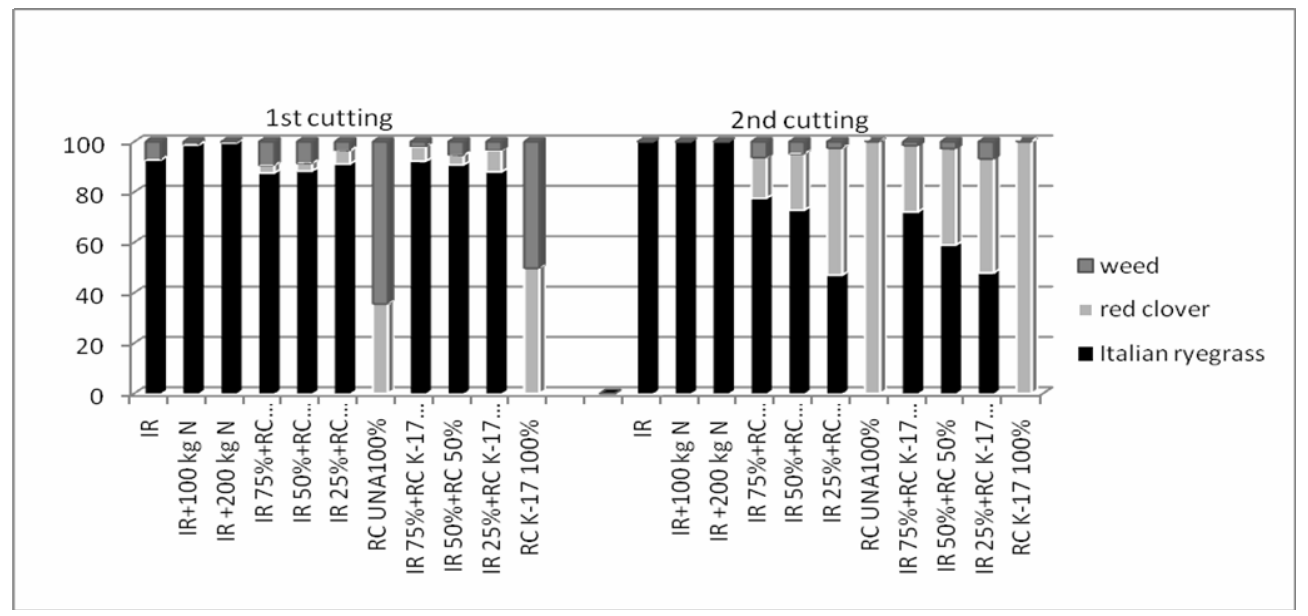

Figure 1. Share of each component (botanical composition) in mixtures per cutting (\%), autumn sowing

Red clover variety K-17 gave the highest forage yield in both production years. The lowest forage yield was achieved by clover variety Una (2.60 $\left.\mathrm{t} \mathrm{DM} \mathrm{ha}^{-1}\right)$, which related to their slow establishment character after autumn sowing (late date of sowing and high percent of hard seeds). Both red clover varieties reached the highest yield of forage production in the ratios 50:50\% with Italian ryegrass. The share of individual botanical constituents in yield was assessed (Figures 1 and 2). Botanical composition of autumn sowing stand showed that grass component represented larger part than it had been at establishment. Nitrogen fertilization bounded weed growth at second cutting and other herbs represented only a small part.

Spring sowing stand and its first production year gave more uniform range of herbage yields. The highest yields were obtained with larger share of red clover component. The red clover contribution to the total DM harvested of the mixtures was the largest at second cutting of spring sowing, also weed content was markedly reduced in comparison with other cuttings. 


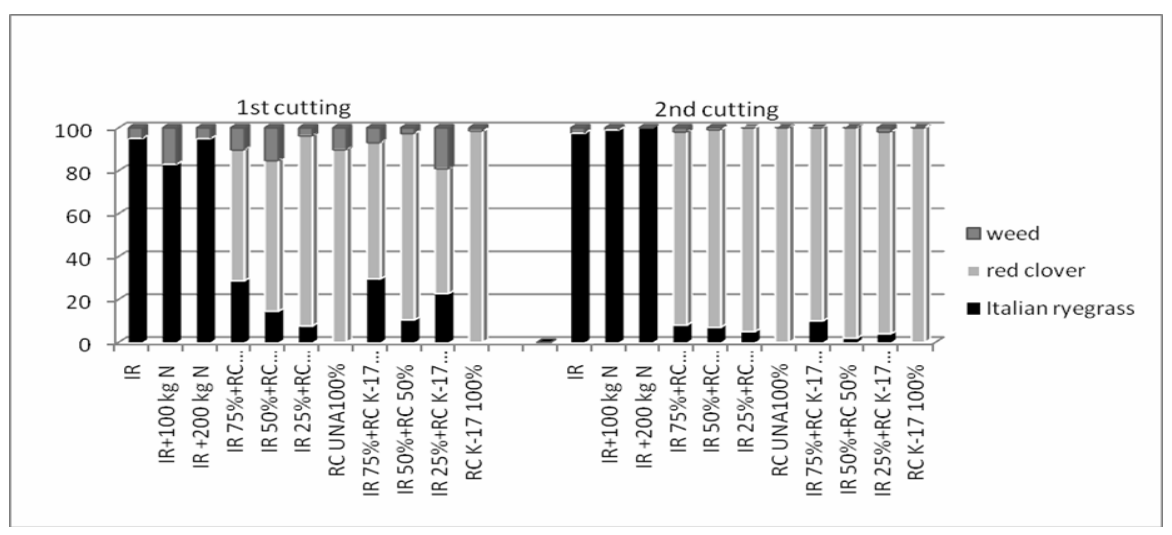

Figure 2. Share of each component (botanical composition) in mixtures per cutting (\%), spring sowing

An experiment conducted to measure the effects of ryegrass and red-clover varieties mixture on the productivity of red-clover swards showed that the addition of a companion grass increased total herbage yields; because of lack of persistence, spring seeded Italian ryegrass yielded poorly the year after establishment. LER index, as the amount of land needed to grow a pure stand to gain the same yield as an intercrop, showed that the first cutting (ratio 50:50 IR:RC Una) in autumn sowing gained the best efficiency of the production area utilization. A companion grass had little effect on red clover yield in the mixed swards. Its presence also reduced the ingress of unsown species. The variety of red clover used had significant effect on total herbage yield in autumn established stand, but had little effect on total yield in spring established stand. A red-clover/grass sward may have advantages over a pure red-clover sward nutritionally. Clover in that mixture has an ability to give high herbage yield of high nutritive value without the addition of fertilizer $\mathrm{N}$.

Table 4. Relative yield (RY) of dry matter and total LER index for intercropped red clover and Italian ryegrass per cutting

\begin{tabular}{|l|c|c|c|c|c|c|c|c|}
\hline \multirow{2}{*}{ Intercrop } & \multicolumn{2}{|c|}{ autumn sowing } & \multicolumn{3}{c|}{ spring sowing } & & \\
\cline { 2 - 9 } & \multicolumn{2}{|c|}{$1^{\text {st }}$ cut } & \multicolumn{2}{|c|}{$2^{\text {nd }}$ cut } & $1^{\text {st }}$ cut & & $2^{\text {nd }}$ cut & \\
\cline { 2 - 9 } & RY & LER & RY & LER & RY & LER & RY & LER \\
\hline IR:RC Una (75\%:25\%) & $1.13: 4.35$ & 5.48 & $0.73: 0.61$ & 1.34 & $1.87: 0.93$ & 2.80 & $4.80: 0.73$ & 5.52 \\
\hline IR:RC Una (50\%:50\%) & $1.44: 5.54$ & 6.98 & $0.68: 0.57$ & 1.25 & $1.99: 0.98$ & 2.97 & $7.33: 1.11$ & 8.44 \\
\hline IR: RC Una (25\%:75\%) & $0.87: 3.33$ & 4.20 & $0.88: 0.74$ & 1.62 & $2.25: 1.11$ & 3.36 & $6.01: 0.91$ & 6.93 \\
\hline IR:RC K-17 (75\%:25\%) & $1.18: 1.30$ & 2.48 & $0.83: 0.69$ & 1.52 & $1.59: 0.76$ & 2.35 & $4.88: 0.68$ & 5.56 \\
\hline IR:RC K-17 (50\%:50\%) & $1.55: 1.72$ & 3.27 & $0.99: 0.83$ & 1.82 & $2.00: 0.95$ & 2.95 & $6.27: 0.88$ & 7.14 \\
\hline IR:RC K-17 (25\%:75\%) & $0.90: 1.00$ & 1.90 & $0.76: 0.64$ & 1.40 & $1.43: 0.63$ & 2.05 & $6.74: 0.94$ & 7.68 \\
\hline
\end{tabular}

Generally, the influence of mixture ratio was less marked than sowing date. The sowing date affects total herbage yield and botanical composition of Italian 
ryegrass/red clover mixture. The botanical composition ratio best persist into the first production year at the second cut of autumn sowing, but the seed rate effects were weak at other cuttings.

\section{Conclusion}

It is concluded that Italian ryegrass can be a suitable companion grass for red clover in the first production year. Its superior yielding capacity over other grasses under a conservation management can be coupled to advantage with red clover to give a sward which is essentially stable, at least over a 2- to 3-year cropping period, although giving slightly reduced yields in the first production year in Serbian conditions. Better stands of Italian ryegrass/red clover mixture were obtained from sowings made in autumn. There was a significant interaction between seed rate and date of sowing. A mixture ratio of 50:50\% proved the most satisfactory. The practical agricultural implications of using Italian ryegrass-red clover mixtures, is production of high DM yields of good quality herbage without the use of $\mathrm{N}$ fertilizer.

\section{Acknowledgment}

Research was financed by the Ministry of Education and Science, Republic of Serbia, Project TR 31016.

\section{Prinos krme travno-leguminozne smeše pri različitom vremenu zasnivanja}

\section{A. Simić, S. Vasiljević, S. Vučković, Z. Tomić, Z. Bjelić, V. Mandić}

U toku vegetacione sezone 2007-2009 izveden je ogled na eksperimentalnom polju Instituta za stočarstvo, Zemun-Beograd, sa crvenom detelinom i italijanskim ljuljem radi uporednog ispitivanja ukupne proizvodnje biomase smeša. Smeše su uključivale dve sorte crvene deteline (K-17 i Una) i tetraploidnog italijanskog ljulja (K-29t) sa različitim proporcionalnim odnosima (100:0\%, 50:50\%, 75:25\%, 25:75\% i $0: 100 \%$ ). Italijanski ljulj sejan u čistom usevu prihranjivan je sa 100 i $200 \mathrm{~kg} \mathrm{~N}^{-1}$. Različito vreme setve uticalo je na prinos krme i botaničku kompoziciju u prvoj proizvodnoj godini. Crvena detelina sejana u proleće bila je otpornija i kumulativno prinosnija, kao i italijanski ljulj sejan u jesen koji je proizveo više suve materije u smeši u odnosu na detelinu. Ogled pokazuje potencijal dve sorte crvene deteline sejane u čistom usevu ili sa italijanskim ljuljem radi dobijanja i održavanja visoke proizvodnje biomase dobrog kvaliteta u prvoj proizvodnoj godini, pri različitom 
vremenu zasnivanja. Razmatrane su praktične agronomske implikacije korišćenja smeše italijanskog ljulja i crvene deteline.

\section{References}

ALBAYRAK S., TÜRK M., YÜKSEL O., YILMAZ M. (2011): Forage yield and the quality of perennial legume-grass mixtures under rainfed conditions. Notulae Botanicae Horti Agrobotanici Cluj-Napoca, 38, 1, 114-118.

FORNARA D. A., TILMAN D. (2008): Plant functional composition influences rates of soil carbon and nitrogen accumulation. Journal of Ecology, 96, 2, 314-322.

HEJDUK S., KNOT P. (2010): Effect of provenance and ploidity of red clover varieties on productivity, persistence and growth pattern in mixture with grasses. Plant Soil Environment, 56, 3, 111-119.

HELGADÓTTIR A., CONNOLLY J., COLLINS R., FOTERGILL M., KREUZER M., LÜSCHER, A., PORQUEDDU C., SEBASTIA M.T., WACHENDORF M., BROPHY C., FINN A.J., KIRWAN L., NYFELER D. (2008): Biodiversity and animal feed - future challenges for grassland production. Proceedings of the $22^{\text {nd }}$ General Meeting of the European Grassland Federation. Uppsala, Sweden, 13, 39-49. NEŠIĆ Z., TOMIĆ Z., KRNJAJA V., TOMAŠEVIĆ D. (2008): Nitrati u biljci i zemljištu nakon đubrenja travnoleguminoznih smeša. Biotechnology in Animal Husbandry, 24(5-6), 95-104.

PAHLOW G. (2003): Preservation of forage legumes. 47. Jahrestagung AGF, Braunschweig, 28-30.8.2003, 23-30.

SIMA N.F., MIHAI G., SIMA R.M. (2010): Evolution of the botanical composition and forage yield of several perennial fodder legume and grass mixtures in the year of establishment. Notulae Botanicae Horti Agrobotanici Cluj-Napoca, 38, 45-50.

SIMIĆ A., ĐORĐEVIĆ N., GRUBIĆ G., VUČKOVIĆ S. (2006): The influence of $\mathrm{N}$-spring application on meadow grass mixture on energy value of produced hay. Biotechnology in Animal Husbandry, 22, spec. issue, 489-497.

SIMIĆ A., VUČKOVIĆ S., KRESOVIĆ M., VRBNIČANIN S., BOŽIĆ D. (2009): Changes of crude protein content in Italian ryegrass influenced by spring $\mathrm{N}$ application. Biotechnology in Animal Husbandry, 25, 5-6-2, 1171-1179.

SULLIVAN M.L., HATFIELD R.D. (2006): Polyphenol oxidase and o-diphenols inhibit postharvest proteolysis in red clover and alfalfa. Crop Science, 46, 662-670.

VASILJEVIĆ S. KARAGIĆ Đ., SIMIĆ A., TERZIĆ D., KATIĆ S., KATANSKI S. (2010): Productivity of Italian ryegrass (Lolium multiflorum L.) and red clover (Trifolium pratense L.) as pure stands and intercrops. NJF Report, 6, 3, 129-132.

WACQUANT J. P. OUKNIDER M., JACQUARD P. (1989): Evidence for a periodic excretion of nitrogen by roots of grass-legume associations. Plant and Soil, 116, 1, $57-68$. 